DOMINIKA CIERNIKOVA ${ }^{1}$

Matej Bel University

Faculty of Natural Sciences
ORIGINALNI NAUČNI RAD

UDK: $\quad 37.091 .3: 51$

37.015.31:51

BIBLID: 0353-7129, 25(2020)2, p.187-197

\title{
EFFECTS OF THE APPLICATION OF OPEN-ENDED TASKS IN MATHEMATICS TEACHING
}

\begin{abstract}
Summary: Learning process, especially during mathematics lesson, is accomplished thanks to the tasks that students are confronted with. A focus of this paper is on open tasks. Its aim is to depict the significance of the open tasks in mathematics teaching with regard to the teachers' work with them. Furthermore, the paper presents the findings about the mindsets of 60 Slovak teachers gained through the online questionnaire. The results indicate that a lot of teachers either do not believe that their students can change their intelligence quotient or cannot decide about this matter. Again, the questionnaire was chosen as the research method to monitor the motivation of students to solve the open tasks. The familiarity of students with this type of tasks seems to raise their interest in solving the open tasks. In addition, few ways of modifying the closed task to the open one are presented in the paper.
\end{abstract}

Key words: mathematics, open problem, open task, closed task, challenging task, growth and fixed mindset

\section{INTRODUCTION}

Mathematics plays an important part in people's lives whether they are aware of it or not. It is not just about calculating different numbers but it can be seen around us in different patterns and structures, in nature or in architecture. Moreover, mathematics involves solving problems and as people are confronted with different problems daily, mathematics can set a good base for facing the problem and not escaping from them.

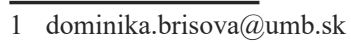


Some of the goals of mathematics presented in Slovak Innovated National Educational Program are:

- to develop learners' ability to use mathematics in the future,

- to develop learners' logical and critical thinking,

- to develop reasoning of their solution of the problem,

- to provide space for communication and cooperation with their schoolmates,

- to enable learners to look at mathematics as at a part of human culture,

- to support learners to use already acquired algorithm when solving a task,

- to support learners to interpret the results of their solution, and others.

These goals are very general and should be achieved through mathematical content that is assigned for every school year. In fact, using open problems in mathematics lessons can meet these demands.

\section{DEFINITION OF OPEN TASKS AND THEIR ADVANTAGES}

Important instrument for forming knowledge, especially during the mathematics lessons, are the tasks that students are confronted with. Hiebert and Wearne (1993) claim that „what students learn is largely defined by the tasks they are given“" (Hiebert and Wearne, 1993, p. 395). Mathematical tasks and problem solving determine the level of students' thinking and, at the same time, the nature of the relationship between the teacher and the students (Clarke and Roche, 2017).

Sullivan (2011) explains that although tasks provide learning opportunities, learning is achieved if ,students have opportunities to make decisions about either the strategy for solving the task or the process they will adopt for addressing the task goal or both. In addition, it is expected that the task will provide some degree of challenge, address important mathematical ideas and foster communication and reasoning. It is only tasks with such features that can stimulate students to engage in creating knowledge for themselves" (Sullivan, 2011, p. 31).

There are different types of tasks in terms of openness and there is not a distinct line between them. We remark that in this paper we will not distinguish between these two concepts - task and problem - as it will not bring any difference in capturing the main point of interest. Pehkonen (1997) defines open problems as the opposite of closed problems. If the starting situation and the goal situation are exactly explained, then the task is closed. If at least one of them is not closed, then the problem is open. He included several types of tasks in the open problems as: open-ended problems, reallife situations, investigations, problem fields, problem variations, projects, problem posing and problems without questions (1997).

Similarly, according to Frobishers (2015a), the openness of a task can be achieved by opening context or the goal. In contrast to Sullivan, they call this type 
of tasks open-ended tasks, because either they can have more than one solution or the goal of the task is not given. Samková et al. (2015) divides open tasks into 3 categories:

- tasks with the open way how to get to the solution,

- tasks with the open ending which offer more possible solutions,

- tasks that can be further expanded.

Kwon (2006) presents these types of open-ended problems: ,(1) overcoming fixations, (2) multiple answers, (3) multiple strategies, (4) strategy investigation, (5) problem posing, (6) active inquiry tasks, and (7) logical thinking" (Kwon, 2006, p. 54).

Accordingly, open tasks can be dealt with from different points of view and there is not a precise definition for them. To avoid misunderstanding, we believe that it is quite convenient to put closed tasks in contrast to open problems as Pehkonen (1997) did.

Open tasks provide a lot advantages for learners. Sawada (in Kwon, 2006) suggests that learners are more active when solving open-ended problems and have less restriction to present their ideas. Frobishers (2015a) consider the open tasks to be rich tasks as they are applicable for all kids, they support learners to make decisions, to reason, they stimulate originality, they are interesting and support questions 'what if...?' and 'what if not..?'. Open tasks are more available for learners than the closed tasks because of learners' different approach to them (Sullivan et al., 2006). Thanks to the open tasks, learners have space to explore and to form their own knowledge, they can compare different results and discuss the different solutions and even more. According to Pehkonen (1997) if tasks do not allow students to apply divergent thinking, the quality of education cannot be enhanced, even after the introduction of new approaches such as small-group cooperative learning and others. Anyway, these new approaches can help to develop the potential that open tasks have.

To sum up, open tasks:

- are available and applicable for all learners,

- stimulate originality and creativity,

- provide space for exploring,

- support decision making, verifying and reflection,

- support questions 'what if...?' and 'what if not...?',

- enable 'aha' effect,

- stimulate discussion among learners,

- imitate real life problems, and more.

Furthermore, Samková (2015) claims that the nature of science can be better understood by solving the open tasks. It is supported by Kuřina (2011) who emphasizes that if mathematicians provide us with just the results of their work then it is confusing to look at mathematics as at the science subject. 


\section{TEACHERS AND THEIR WORK WITH TASKS}

Although tasks can have a potential for learning and deepening knowledge, their success depends on related work of teachers. If a teacher leads a student through the solution by the approach 'step by step' and learner eventually comes to the correct solutions, that does not necessarily mean that the student mastered the intended topic. If a teacher does not enable learners to discuss their solutions, learners will not have to learn to use mathematical language, to compare their own solutions and to choose the more effective way to solve a task. Furthermore, teachers are often encouraged to limit uncertainty from what students produce or how they produce it and as a consequence, students tend to work with routine problems within a routine environment (Beghetto, 2017). The routine problems have their role in students' learning, but if students are confronted with this type of tasks most of the time, then their creative thinking and originality will be suppressed (Beghetto, 2017). For this reason, teachers need to set an environment for learners that enhances learning and supports students' motivation to learn. One of the successful ways how teachers should deal with the open tasks is to follow constructivist approach presented by Hejný and Kuřina (2015). Teachers should provide such conditions during the lessons so that:

- the activity would be on the side of learners,

- learners would be searching for relations, generalization and its proof,

- learners would construct their knowledge, it would not be transferred from teacher to student,

- learning would be supported by experience,

- the stimulating environment would be set,

- social interaction among learners would be supported,

- different representation of the same information would be provided,

- communication using mathematical language would be formed,

- educational process would be evaluated from at least three points - understanding mathematics, mastering mathematical skills and application of mathematics,

- they avoid creating the formal knowledge, which is memorization of certain steps or information without proper understanding that leads to fast forgetting.

Another way for supporting work with open tasks, is to create brain-compatible environment, which is the environment with regard to the brain and its function. It is closely described in the work of Kovalik (1996).

Students' motivation to deal with challenging problems, such as open tasks, can be closely related to their mindset. It is known that teachers' beliefs about their students might influence students themselves. Moreover, the tasks that teachers choose to solve with their students during the mathematics lessons could be influenced by 
teachers' beliefs about their students' competence. As a result, students might not be confronted with challenging tasks on a sufficient level.

Boaler (2015) claims that 'growth mindset' can be very helpful in the process of learning, as she believes that that shifting from a fixed mindset to a growth mindset can cause higher mathematics achievements. 'Growth mindset' and 'fixed mindset' are closely described in the work of Dweck (2016). Shortly explained, people with 'fixed mindset' believe that their intelligence is more or less fixed. On the other side stand people with 'growth mindset' who believe that their intelligence can grow and they can learn anything. Among these two groups are people who waver between those two mindsets. Dweck (2016) presents the idea that people with the growth mindset do better in life as they work hard and they are persistent, they are successful in life. To find out whether one's mindset is fixed or growth, Dweck formulates 4 statements. According to their acceptance it is possible to define the two mindsets.

1. Intelligence is something basic that you cannot really change.

2. You can learn new things but you cannot really change the level of your intelligence quotient.

3. It does not matter how intelligent you are right now, you can change it quite a lot.

4. You can always change a lot the level of your intelligence quotient (Dweck, 2016).

If there is the acceptance of the first two statements and disapproval of two others, then the mindset is fixed. If it is vice-versa, then it indicates the growth mindset.

\section{MeTHOdS AND RESUlTS}

For the mentioned reasons, we aimed at the teachers in Slovakia and their attitude towards the possibility of changing learner's intelligence quotient. The online questionnaire was used as the research method. It contained different statements and teachers could express the level of agreement to those statements by choosing one option on the scale: I totally agree - I rather agree than do not agree - I do not know - I rather disagree than agree - I completely disagree. Among other statements we included 4 statements that Dweck designed, but the word 'you' was replaced by 'the learners'. If their assessment of the statements corresponded with at least three statements with the fixed (or growth) mind then we indicated their mindset as fixed (or growth). Based on the same condition, if it was not able to assign them to the fixed or growth mindset then they were assigned to mixed mindset.

The questionnaire was conducted by 60 Slovak teachers of mathematics at the second primary education stage with different years of practice. Among the teachers who took part in the questionnaire was only one man, the rest of the teachers were 
women. According to their answers, 22 of them had growth mindset, 12 fixed and 26 mixed mindset.

The results are quite interesting. More than half of these teachers either do not believe that their students can actually change their intelligence quotient or could not decide about this matter. This attitude can play an important role during the lessons. If a teacher does not believe that a particular student can manage to solve a task by himself or herself then the teacher tends to provide learner certain procedure how he or she can get to the solution. Although, teachers can consider the given procedure as helpful, the truth is, that they might suppress learning process and support the creating of only formal knowledge. Moreover, creativity and originality are quite demanding in the labour market nowadays and mathematics has potential to develop these characteristic features. It cannot be achieved if it is common for teachers to demonstrate certain procedures to their students and that is followed by repetitious practice of similarly constructed examples from the side of students. To respond to the demands of the labour market, a different approach to teaching mathematics is required, not just in using different kinds of tasks but also in work with them. Anyway, using more challenging tasks can be the first step.

The quasi-experiment is taking place in four classes of the ninth grade in Slovakia. It aims at using open tasks in the mathematics lessons and monitors their contribution to learners' work with more challenging tasks such as the tasks in PISA testing. Students involved in the experiment are divided into experimental and control group. In the experimental group, teachers are using open tasks in their lesson in contrast to control group, where students do not solve open tasks at all or have very little experience with such type of tasks. As a part of this research a short survey was conducted with the aim to find out whether the learners familiar with the open tasks would be more eager to solve them than the learners with low experience of this type of tasks. As the open tasks provide a big potential for learning, it would be important to know that learners want to solve such problems. Their motivation to solve these tasks provides the base for fulfilling other goals in mathematics, such as exploring, reasoning, generalization, deepening understanding, social interaction and others.

For this reason, a questionnaire was created, which contained 3 sets of tasks. Every set further consisted of 2 tasks, one was open and the other was closed. It was in the paper form and was filled in by 58 nine graders (their age is from 14 to 15 years). Half of them was from experimental group, we will call these students Group E (=experimental) and the other half was from control group, which will be marked as Group C (=control). In the questionnaire, students were supposed to choose which of the two tasks in every set they would rather solve. After making a choice, they were supposed to reason their choice. The tasks were taken from the fields The Powers and Roots and The Pythagorean Theorem. In Slovakia, both of these fields are recommended to be taught in the ninth grade. We wanted learners to be familiar with the topics so that the fear from the unknown would not stand as an obstacle to choose a task. 
In the following part of this paper, the sets of the tasks given to students in the questionnaire are presented as well as students' reasons why they chose the particular option.

\section{Set 1}

Task A: Find the lengths of the legs of the right triangle, if the hypotenuse is $6 \mathrm{~cm}$.

Task B: The hypotenuse in the right triangle is $6 \mathrm{~cm}$, one of the legs is $3 \mathrm{~cm}$ long. Find the length of the third side of this triangle.

Task A is an open task, as only one side length of the right triangle is given. Except for the Pythagorean Theorem, one needs to keep in mind the triangle inequality to find a solution. In the Group E $37,9 \%$ of the students preferred to solve the open task in compare with $24,1 \%$ students in the Group C. More than half of the students in both groups chose the closed task. Most common reasons for the closed task were: (i) it was easier to understand and to solve, (ii) they knew right away how to solve it, (iii) it required less time and less effort. For some, the open task was easier or they chose the open task because it contained less text.

\section{Set 2}

Task A: Find the value of $x$ and $y$ so that the equality holds: $3^{x} \cdot 3^{y}=3^{7}$.

Task B: Find the value of $x$ so that the equality holds: $3^{x} \cdot 3^{3}=3^{7}$.

If learners are encouraged to write $3^{7}$ in the expanded form, then deeper understanding of multiplication of two powers with the same base can be achieved through the task A. The task A also includes the task B if we ask learners to find all possible solutions. A lot depends on how the teacher would work with such a task.

$41.4 \%$ of the Group E would rather solve the open task in comparison with $27.6 \%$ of the students from the Group C. Many of the students who chose the open task revealed that one of the reasons why they chose that particular option was that they had already solved a similar task. Learners who chose closed task explained that it was easier, they did not have to make any other decisions about the exponents and it required less time as the solution was only one.

\section{Set 3}

Task A: The perimeter of a triangle is $12 \mathrm{~cm}$. Find the side lengths so that the triangle is not right. 
Task B: The side lengths of the triangle are $3.5 \mathrm{~cm}, 3.5 \mathrm{~cm}$ and $5 \mathrm{~cm}$. Find out, whether the triangle is right.

The task $\mathrm{A}$ is the open one, it encourages the learners to choose the side lengths observing the perimeter. After they make a choice they need to check whether the Pythagorean Theorem holds. Moreover, the triangle inequality needs to be checked too, while in the task B learners need to check only the Pythagorean Theorem.

Only $10.7 \%$ of Group E would rather solve the open task in comparison with $25 \%$ of pupils in the Group C. This result was rather surprising but looking at reasons for their choice more than $10 \%$ of learners in Group C have already solved a similar task.

As a result of the survey, the popularity of solving open task rises when students are familiar with this type of tasks. Moreover, if solving open tasks during the lesson is supported by encouraging learners to take a risk, to try different methods, not to be afraid of being wrong, to search for the most convenient way of solving, then learner's motivation to solve challenging tasks can rise. Solving open tasks during the lesson could stand as motivation to solve more difficult tasks in mathematics as some students presented in the questionnaire.

\section{TECHNIQUES TO OPEN A CLOSED TASK}

Teachers might consider the curriculum responsibilities as overwhelming and believe that there is not time use different type of tasks in the lessons. The truth is that if a teacher masters a skill to transform a routine tasks into non-routine problems then the teacher does not need to $a d d$ non-routine tasks to their curriculum (Beghetto, 2017) but by transforming an existing task the teacher can promote it to a higher level, which enables learners to deepen their understanding of particular information. There are different approaches to open a closed task that can be found for example in the work of Boaler (2015) and Frobishers (2015b). Simply explained Boaler's idea, instead of asking students to solve a simple exercise (i) they should be encouraged to explain it and support is by visual illustration, (ii) they should be asked to solve it in many different ways, (iii) they should find a generalization that holds.

Frobishers (2015b) propose 2 different ways of opening a closed task - a simple and systematic way. Simple way involves transforming a task so that it includes the word explore. Systematic way consists of more steps: (i) firstly analyzing the attributes of the task, (ii) using question "what if...?" for the chosen attributes, (iii) writing down the tasks created after using question "what if...?". For example, let's look at the task:

The hypotenuse of the right triangle is $6 \mathrm{~cm}$ long, one of his legs is $5 \mathrm{~cm}$ long. Find the length of the other leg.

The attributes of this task are:

1. The task is closed.

2. The task has only one possible solution. 
3. It involves a triangle.

4. The triangle is right.

5. The lengths of 2 sides of the triangle are given.

6. One of the given sides is the hypotenuse, the other is leg.

7. The unknown side is the leg of the right triangle.

8. The sizes of both given sides are in $\mathrm{cm}$.

It would be convenient to apply the question "what if...?" for the attributes (4), (5), (6) and (7). Some of the "what if...?" questions can look like this:

- What if the triangle was not right?

- What if only one side length was given?

- What if only the length of the hypotenuse was given?

- What if only the length of one leg was given?

- What if only the ratio of two legs was given?

- What if only the sum of two legs was given?

- What if only the sum of two side lengths was given?

- What if it was not mentioned that the given side lengths are for the hypotenuse and for the leg?

- What if only the areas of the squares on the hypotenuse and one leg were given?

- What if the area of square on only one side was given?

- What if the unknown side was the hypotenuse?

- What if the unknown were two sides?

As a response to these questions, different tasks can be created. This way does not necessarily lead to only open tasks. By this technique, closed tasks can be created too, but they might propose a different level of difficulty than the original task. Anyway, mastering Frobishers' systematic technique for opening a closed task can save a lot of time and can help to provide learners with interesting and challenging tasks that at the same time reflect the current level of students' knowledge about the given topic according to teachers' work with them.

\section{Conclusion}

In our opinion, the issue of open tasks is relevant and can be proposed as a reaction to bring changes into mathematics education. Involving open tasks into educational process can bring many advantages. Despite the potential they have, teachers need to choose a proper approach to fulfill their potential, otherwise their contribution does not have to be significant. Growth mindset can be helpful when working with open task as well as stimulating environment that provides space for students to be active in making decisions, to explore different relations, to discuss different solutions, to 
transfer real context to mathematical one, to interconnect mathematics with different subjects, to apply higher thinking processes and others. There are more techniques which teachers can follow to form open tasks that simply transfer an existing close task into an open one and thus the teacher can provide learners with interesting tasks without any difficulties. In addition, students' familiarity with the open tasks supports their motivation to solve this type of tasks and that prepares a good base for achieving other goals.

\section{REFERENCES}

Beghetto, R. A. (2017). Lesson unplanning: toward transforming routine tasks into non-routine problems. Mathematics Education Research Journal, 49, 987-993.

Boaler, J. (2015). Mathematical Mindsets. Chichester, United Kingdom : Jossey Bass Wiley.

Clarke, D., \& Roche, A. (2017). Using contextualized tasks to engage students in meaningful and worthwhile mathematics learning. Journal of Mathematical Behavior.

Dweck, C. S. (2016). Mindset: The New Psychology of Success. New York : Ballantine Books Inc.

Frobisher, L., \& Frobisher, A. (2015a). Didaktika matematiky I. Bratislava : Dr. Josef Raabe Slovensko, s. r. o.

Frobisher, L., \& Frobisher, A. (2015b). Didaktika matematiky II. Bratislava : Dr. Josef Raabe Slovensko, s. r. o.

Hejný, M., \& Kuřina, F. (2015). Dítě, škola a matematika: Konstruktivistické př́stupy k vyučování (3. vyd.). Praha : Portál.

Hiebert, J., \& Wearne, D. (1993). Instructional Tasks, Classroom Discourse and Students' Learning in Second-Grade Arithmetic. American Educational Research Journal, 30, 393-425.

Kovalik, S. (1996). Integrované tematické vyučovanie: Model. Bratislava : FABER.

Kuřina, F. (2011). Matematika a řešení úloh. České Budějovice : Jihočeská univerzita, Pedagogická fakulta.

Kwon, O. N., Park, J. S., \& Park J. H. (2006.) Cultivating divergent thinking in Mathematics through an open-ended approach. In Asia Pacific Education Review, 7, 51-61.

Pehkonen, E. (1997). Use of Open-Ended Problems in Mathematics Classroom. Research Report 176. University of Helsinki. Department of Teacher Education.

Samková, L., Hošpesová, A., Roubíček, F., \& Tichá, M. (2015). Badatelsky orientované vyučování v matematice. In Scientia in educatione, 6, 91-122.

Sullivan, P. (2011). Teaching Mathematics: Using Research-informed Strategies. Australian Education Review, 59. 
Sullivan, P., Mousley, J., \& Zevenbergen, R. (2006). Teacher Actions to Maximize Mathematics Learning Opportunities in Heterogeneous Classrooms. International Journal of Science and Mathematics Education, 4, 117-143.

\title{
Эффекты применения заданий открытого типа в обучении математике
}

\begin{abstract}
Аб̆стракт: При обучении математике большая часть времени отводится решению задач. В данной статье рассматриваются задачи открытого типа на уроке математики. Целью исследования было подчеркнуть значимость использования учителем заданий открытого типа на уроке математики. В статье приводятся результаты анкетирования 60 словацких учителей. Результаты показывают, что большинство преподавателей не верят в то, что задания открытого типа могут повысить уровень знаний учеников или не имеют четкой позиции по этому вопросу. В качестве метода исследования заинтересованности студентов в использовании заданий открытого типа также было выбрано анкетирование. По ознакомлении учащихся с этим типом заданий, интерес с их стороны повышался. В статье приводятся несколько способов преобразования заданий закрытого типа в задания открытого типа.

Ключевые слова: математика, открытая проблема, открытое задание, закрытое задание, настройка мысли
\end{abstract}

\section{Ефекти примене задатака отвореног типа у настави математике}

Резиме: Процес учења, посебно током часа математике, остварује се захваљујући задацима са којима се ученици суочавају. Фокус овог рада је на задацима отвореног типа. Циљ је да се прикаже значај задатака отвореног типа у настави математике у односу на бављење наставника њима. Поред тога, у раду су представљени налази о начину размишљања 60 словачких наставника добивеним путем онлајн упитника. Резултати указују на то да многи наставници или не верују да њихови ученици могу променити коефицијент интелигенције или не могу одлучити о овом питању. Упитник је поново изабран као истраживачка метода за праћење мотивације ученика при решавању задатака отвореног типа. Упознатост ученика са овом врстом задатака, чини се, повећава њихово интересовање за решавање задатака отвореног типа. Поред тога, у раду је представљено неколико начина трансформације затвореног задатка у отворени.

Кључне речи: математика, задатак отвореног типа, задатак затвореног типа, задатак изазова, раст и фиксни начин размишљања. 